\title{
REFUSAL STRATEGIES IN PERCY JACKSON THE LAST OLYMPIAN AND ITS TRANSLATION
}

\author{
M Rifanda ${ }^{1}$, MR Nababan ${ }^{2}$ and Djatmika ${ }^{3}$ \\ \{1rifanda.maruf_20@student.uns.ac.id, ${ }^{2}$ amantradja@yahoo.com, ${ }^{3}$ djatmika@uns.ac.id\} \\ ${ }^{1}$ Graduate Student of Department of Linguistics, Universitas Sebelas Maret, \\ ${ }^{2,3}$ Department of Linguistics, Universitas Sebelas Maret
}

\begin{abstract}
This study aims at identifying what refusal strategies in Percy Jackson \& The Olympians: The Last Olympia and how they are transferred into their translation. There are twenty-one data gained from chapter one to chapter twenty-three of the novel. First, the researcher identifies the refusal speech act in Percy Jackson \& The Olympians: The Last Olympia, the utterances then classified based on the refusal strategy applied in the context. The utterances then were analyzed and described based on the situational context. The analysis also explains why the speaker apply this strategy. The strategy used in the source text is then compared to that in the target text. Based on the data analysis, this study found that both direct and indirect refusal strategies were applied. The most dominant strategy applied, however, is indirect. Morever, the refusal strategies were compared to the translation version in order to find out the shift on refusal strategy.
\end{abstract}

Keywords: speech act, refusal strategy, translation, novel

\section{Introduction}

Translation is rendering the meaning of a text into another language as it is intended by its author [1]. Translation, however, is not simply transferring the messages from the source text into the target text due to its process of getting the messages is not an easy feat. Every language has its own way to package its meaning. The meaning components are packaged into lexical items but the way it is packaged is different from one language to another as stated by [2]. Even though translation is basically a change in form [3] transferring message from one language into another is not as simple as merely transforming the form of the part of the language. It is thanks to the translation process involves two different language which are not only in form of system, which is surface structure, but also in its deep structure.

As translation is not simply changing the 1 form of the language in order to transfer its messages, translation needs other disciplines to work with messages. In the process of transferring messages, some apparatus to identify meaning are needed. Linguistics is a discipline which bridges to understand the messages behind both the source and the target text.

Text can only be approached through interpretation as simply transferring word for word during translation process can cause its messages meaningless and illogical. It is due to the correspondence between orthographic words and element of meaning are different from one 
language to another [4]. Therefore, involving context in understanding the meaning is a must. Context comprises situational and cultural. Situational context is who speaks to whom, where, in what condition, and for what reasons an utterance appears [5]. A single utterance, however, may convey different meaning in different situation and cultural background which then leads to opposite interpretation depending on the context in which it is processed. Cultural context, on the other hand, comprises all the values, belief system, and also the history that shape a society. Thus, understanding both source and target language cultural background is essential for a translator. It is in line with [6] stated that translation is communicative process in a certain social context.

Pragmatics is one of the linguistics branches that studies about the context of speech act not only in a conversation but also in writing text [7]. The focus of this study lies in the translation study and pragmatics that is to analyze the meaning of the speech rather than the meaning of the utterance. Consequently, pragmatics plays a great role in the discussion of translation as it may be fatal not to involve pragmatics in the discussion of translation studies.

There have been many studies in pragmatics as well as in translation. Ref [8] investigates about the speech act used in Kaba. While [9] investigates the directive speech act used in the transaction sale at Watampone central market. Moreover, this study tries to investigate refusal speech act and what refusal strategy which was applied by the speaker. The analysis of the refusal strategy was based on [10].

\section{Research Method}

\subsection{Data Collection}

The data of this study refer to sentences accomodating refusal speech act taken from novel Percy Jackson \& The Olympians: Last Olympian.

\subsection{Data Analysis}

Data analysis was based on three main research questions, namely: 1) What are the refusal stategies applied in the novel? 2) How are they applied? 3) Was there any strategy shift found in the translation version?

This study employed a pragmatic analysis approach to examine the refusal strategy. In order to examine the existance of the shift in refusal strategy, the data from both version of the novel were compared.

\section{Results And Discussion}

\subsection{General Description of the Data}

Based on the categories of the part of speech, there are twenty-three utterances which accommodate the refusal speech act found in the first twenty-three chapter of the novel. The utterances, then, are categorized based on the refusal strategy which then come to the following table. 
Table 2.1.1 Distribution of the Refusal Strategy

\begin{tabular}{cllc}
\hline No & & \multicolumn{1}{c}{ Refusal Strategy } & Number of Items \\
\hline $\mathbf{1}$ & Direct & A. Non-Performative & 8 \\
& & B. Performative & 0 \\
& \multirow{2}{*}{ Indirect } & A. Excuse, Reason, Explanation & 5 \\
& & B. Attempt to Dissuade the Interlocutor & 4 \\
& & 2 & 2 \\
& C. Statement of Alternative & 1 \\
& D. Avoidance & 1 \\
& E. Statement of Principle & 0 \\
& F. Acceptance that Functions as Refusal & 0 \\
& G. Statement of Regret & 0 \\
& H. Wish & 0 \\
& I. Set Condition for Future Acceptance & 0 \\
\hline
\end{tabular}

It was found out that direct strategy: non-performative is the most refusal strategy applied in the refusal speech act in Percy Jackson \& The Olympians: The Last Olympia. The table below describes the distribution of the refusal speech act and refusal strategy.

\subsection{How Refusal Strategies is Applied and How It is Transferred into the Target Text}

\subsubsection{Direct Strategy}

This study found that there were eight utterances applying direct refusal strategy. This strategy is categorized to two types, performative and non-performative [11]. There only are non-performative strategy found in this study. One of the examples is the conversation between Nico and Percy.

Table 3.2.1 The Utterance of Direct Strategy

\begin{tabular}{cll}
\hline No & Source Text & Target Text \\
\hline 4 & No! & Nggak! \\
\hline
\end{tabular}

This conversation happened when Percy gave another alternative (in order to refuse Nico's suggestion) but Nico did not like what Percy suggested. He then refused Percy's suggestion by stating "No!". This indeed is a direct refusal strategy. This is not a performative strategy but non-performative as Nico did clearly say "No!" instead of "I refuse". The translation is in the same strategy. "No!" is translated into "Nggak!" which incorporates the same direct refusal strategy: non-performative. In other word, they both apply direct refusal strategy: nonperformative. Thus, there is no refusal strategy shift.

\subsubsection{Indirect Strategy}

There are fifteen utterances applying this indirect strategy. Indirect strategy is then categorized to eleven different categories as proposed by [12]. The indirect strategy found in this study were only six instead of eleven. They are excuse, reason, explanation strategy, attempt to dissuade the interlocutor strategy, statement of alternative strategy, avoidance strategy, statement of principle strategy, and acceptance that functions as refusal strategy.

\subsubsection{Excuse, Reason, Explanation}

There are four utterances applying indirect refusal strategy: excuse, reason, explanation. One of the examples is the conversation between Percy and his father, Poseidon The God of the Sea. 
Table 3.2.2.1 The Utterance of Indirect Strategy: Excuse, Reason, Explanation

\begin{tabular}{cll}
\hline No & \multicolumn{1}{c}{ Source Text } & \multicolumn{1}{c}{ Target Text } \\
\hline 2 & $\begin{array}{l}\text { It is bad enough I must send you into } \\
\text { danger. Tyson is too young. I must } \\
\text { protect him. }\end{array}$ & $\begin{array}{l}\text { Sudah cukup buruk aku mesti mengirimmu ke } \\
\text { tengah bahaya. Tyson masih terlalu muda. Aku } \\
\text { harus melindungi-nya. }\end{array}$ \\
\hline
\end{tabular}

This conversation is about Percy suggested his father to put more faith in his son. Poseidon, on the other hand, did not want his sons to be hurt and tried to protect his sons. That is why he responded that way and it was an act of refusing. He refused Percy's request by station his excuse, reason, and explanation. The translation is in the same strategy. "It is bad enough I must send you into danger. Tyson is too young. I must protect him." is translated into "Sudah cukup buruk aku mesti mengirimmu ke tengah bahaya. Tyson masih terlalu muda. Aku harus melindungi-nya." which incorporates the same indirect refusal strategy: excuse, reason, explanation. In other word, they both apply indirect refusal strategy: excuse, reason, explanation. Thus, there is no refusal strategy shift in the translation.

\subsubsection{Attempt to Dissuade the Interlocutor}

There are four utterances applying indirect refusal strategy: attempt to dissuade the interlocutor. One of the examples is the conversation between Percy and the gatekeeper.

Table 3.2.2.2 The Utterance of Indirect Strategy: Attempt to Dissuade the Interlocutor

\begin{tabular}{cll}
\hline No & \multicolumn{1}{c}{ Source Text } & \multicolumn{1}{c}{ Target Text } \\
\hline 9 & $\begin{array}{l}\text { Forty demigods attract an awful lot of } \\
\text { monsters. }\end{array}$ & $\begin{array}{l}\text { Empat puluh blasteran menarik banyak sekali } \\
\text { monster. }\end{array}$ \\
\hline
\end{tabular}

This conversation happened when the gatekeeper tried to chase away Percy and his demigod friends from the building. Percy, however, refused his attempt to chase him away, applying attempt to dissuade the interlocutor strategy, by stating that way which can be seen as threatening act. This, however, is indeed a threatening act but as [13] proposed this can be categorized as an attempt to dissuade the interlocutor which is an attempt to refuse. The translation is in the same strategy. "Forty demigods attract an awful lot of monsters." is translated into "Empat puluh blasteran menarik banyak sekali monster." which incorporates the same indirect refusal strategy: attempt to dissuade the interlocutor-attack/threaten. In other word, they both apply indirect refusal strategy: attempt to dissuade the interlocutor. Thus, there is no refusal strategy shift in the translation.

\subsubsection{Statement of Alternative}

There are two utterances applying indirect refusal strategy: statement of alternative. One of the examples is the conversation between Percy and Nico.

Table 3.2.2.3 The Utterance of Indirect Strategy: Statement of Alternative

\begin{tabular}{ccc}
\hline No & Source Text & Target Text \\
\hline 7 & You'll be more help down here. & Empat puluh blasteran menarik banyak sekali monster. \\
\hline
\end{tabular}

This conversation happened when Percy suggested that Nico should stay within the Underworld instead of joining him to come back to the upperworld. Nico, then, refused Percy's suggestion because he was afraid of his father, Hades. After hearing Nico's refusal and Nico insisted to go with Percy, Percy refused Nico's request by stating that Nico would be more help in the Underworld, helping his father. Thus, Percy applied indirect refusal strategy: statement of alternative. The translation is in the same strategy. "You'll be more help down 
here." is translated into "Empat puluh blasteran menarik banyak sekali monster." which incorporates the same indirect refusal strategy: statement of alternative. In other word, they both apply indirect refusal strategy: statement of alternative. Thus, there is no refusal strategy shift in the translation.

\subsubsection{Avoidance}

There are two utterances applying indirect refusal strategy refusal: avoidance. This strategy is categorized as verbal and non-verbal [14]. The applied strategy in this finding is verbal avoidance as the data are utterances. One example of the data is a conversation between Rachel and her father when they were at their long-awaited vacation.

Table 3.2.2.4.1 The Utterance of Indirect Strategy: Avoidance

\begin{tabular}{ccc}
\hline No & Source Text & Target Text \\
\hline 11 & Back? We just got here. & Kembali? Kita baru sampai di sini. \\
\hline
\end{tabular}

Rachel asked her father to come back to New York even though they were just arrived to their vacation place. Hearing her daughter request, he then refuse her daughter request by applying non-verbal avoidance repeating the part of the request. By repeating the part of the request can be considered as an act of refusing because he clearly understands what her daughter asked, but he, instead of, directly refusing her daughter's request he chose to ask her daughter what she asked. The translation is in the same strategy. "Back? We just got here." is translated into "Kembali? Kita baru sampai di sini." which is exactly repeating the part of the request. Therefore, there is no strategy shift in the translation. Thus, they both apply indirect strategy: avoidance-verbal-repetition of part of request.

Table 3.2.2.4.2 The Utterance of Indirect Strategy: Avoidance

\begin{tabular}{ccc}
\hline No & Source Text & Target Text \\
\hline 10 & Um, Percy, Manhattan is huge. & Eh, Percy, Manhattan besar lho. \\
\hline
\end{tabular}

The other example of indirect refusal strategy: avoidance is one that uttered by Silena. This conversation happened when Percy asked his demigod friends to hold Manhattan from enemy's attack. Percy's request seemed very demanding and that was why Silena responded Percy's request by hesitantly stating that way. [15] proposed that hesitant is a non-verbal refusal act but the way Silena responded Percy is clearly hesitating. Therefore, this could be a new finding to what [16] proposed. Moreover, the translation is in the same strategy. "Úm, Percy, Manhattan is huge." is translated into "Eh, Percy, Manhattan besar lho." which is incorporating the same the same strategy, hesitating. Thus, there is no strategy shift. They both apply indirect strategy: avoidance-verbal-hesitation.

\subsubsection{Statement of Principle}

There is only one utterance found applying indirect refusal strategy: statement of principle. The example below is a conversation between Hades and Nico.

Table 3.2.2.5 The Utterance of Indirect Strategy: Statement of Principle

\begin{tabular}{ccc}
\hline No & Source Text & Target Text \\
\hline 17 & I don't have to do anything! & Aku tidak harus melakukan apa-apa! \\
\hline
\end{tabular}

This conversation happened when Nico insisted to persuade her father, Hades, to help Olympus as Olympus is under attack. Hades, on the other hand, insisted in refusing to give a 
hand to Olympus army because he is upset at Zeus as Zeus demoted him to go underworld. Therefore, he applied statement of principle refusal strategy because he is upset at Olympian Council in particular and Zeus in specific [17]. Hades' utterance, "I don't have to do anything!" is translated into "Aku tidak harus melakukan apa-apa!" which applies the same refusal strategy. So, there is no shift of refusal strategy in the translation. They both apply indirect refusal strategy: statement of principle.

\subsubsection{Acceptance that Functions as Refusal}

There is only one utterance found applying indirect refusal strategy: acceptance that functions as refusal. The example is the conversation between Krios and Hyperion.

Table 3.2.2.6 The Utterance of Indirect Strategy: Acceptance that Functions as Refusal

\begin{tabular}{lcl}
\hline No & \multicolumn{1}{c}{ Source Text } & \multicolumn{1}{c}{ Target Text } \\
\hline 1 & $\begin{array}{l}\text { I always get the stupid jobs. Lord of the } \\
\text { South. Lord of Constellations. Now I get } \\
\text { to babysit Atlas while you have all the } \\
\text { fun. }\end{array}$ & $\begin{array}{l}\text { Aku selalu mendapat pekerjaan bodoh. Penguasa } \\
\text { harus mengasuh Atlas sementara kau bersenang- } \\
\text { senang. }\end{array}$ \\
\hline
\end{tabular}

The conversation happened when Hyperion asked Krios to guard mountain Othyrs instead of letting him to join the attacking forces. Krios, then, refusal the order given by Hyperion by complaining. Even though he seemed complaining a lot and showed lack of interest, he still did what he was asked for. That can be considered that Krios applied indirect refusal strategy: acceptance that functions as refusal because showing lack of interest is one of this strategy categories. The translation is in the same strategy. "I always get the stupid jobs. Lord of the South. Lord of Constellations. Now I get to babysit Atlas while you have all the fun." is translated into "Aku selalu mendapat pekerjaan bodoh. Penguasa Selatan. Sang Penguasa Konstelasi. Sekarang aku harus mengasuh Atlas sementara kau bersenang-senang." which applies the same refusal strategy. So, there is no shift of refusal strategy in the translation. They both apply indirect refusal strategy: acceptance that functions as refusal.

\section{Conclusion}

From the description and discussion above, there are some conclusion derived. The first conlusion is there is only one direct refusal strategy proposed were applied in the refusal speech act in Percy Jackson \& The Olympians: The Last Olympia. The strategy is nonperformative [18].

Secondly, out of 11 strategies, only six indirect refusal strategies proposed by were applied in the refusal speech act in Percy Jackson \& The Olympians: The Last Olympia. They are excuse, reason and explanation, attempt to dissuade interlocutor, statement of alternative, statement of principle, acceptance that functions as refusal, and avoidance.

The third conclusion is all strategy applied in the source text are transferred exactly the same strategy into the target text. Thus, there is no strategy shift.

The last is there has been found a new category in indirect refusal strategy: avoidance. Hesitation was firstly proposed by as indirect refusal strategy: avoidance-nonverbal act but this study found that hesitation was also found in indirect refusal strategy: avoidance-verbal. 


\section{References}

[1] P. Newmark, A Textbook of Translation. Singapore: Prentice Hall, 1988.

[2] D. P. Verity and M. L. Larson, "Meaning-Based Translation: A Guide to Cross-Language Equivalence," Lanham: University Press of America, 1986.

[3] M. Baker, In Other Words: a Coursebook on Translation. London/New York: Routledge, 1992.

[4] E. A. Nida, "Contexts in Translating". Amsterdam: John Benjamins Publishing Co., 2001.

[5] B. Hatim and I. Mason, "The Translator as Communicator", London/New York: Routledge, 1997.

[6] A. Aloojaha, M. R. Nababan, and D. Djatmika, "The Impact of Translation Techniques on Shifting Meaning of Ordering Speech Act," Ling. Cult., vol. 12, no. 3, p. 279, 2018.

[7] N. Juita, "Characters Speech Act in Kaba: Wisdom and Language Politeness Reflection of Minangkabau Ethnic," Humanus, vol. XV, no. 1, pp. 92-104, 2016.

[8] M. Safar, "Directive Act in the Transaction Sale At Central Market of Watampone Tindak Tutur Direktif Dalam Transaksi Jual Beli Di Pasar Sentral Watampone," Humanus, vol. XV, no. 2, pp. 167-176, 2016.

[9] L. M. Beebe, T. Takahashi, and R. Uliss-Weltz, "Pragmatic transfer in ESL refusals," Dev. Commun. competence a Second Lang., no. January 1990, pp. 55-70, 1990.

[10] A. Wijayanto, "The Emergence of the Javanese Sopan and Santun (Politeness) on the Refusal Strategies Used by Javanese Learners of English.," Internet J. Lang. Cult. Soc., vol. 36, no. 36, pp. 34-47, 2013.

[11] A. Q. Abed, "Pragmatic Transfer in Iraqi EFL Learners' Refusals," Int. J. English Linguist., vol. 1, no. 2, pp. 166-185, 2011.

[12] M. Aliakbari and M. Changizi, "On the realization of refusal strategies by Persian and Kurdish speakers,” Int. J. Intercult. Relations, vol. 36, no. 5, pp. 659-668, 2012.

[13] S. H. T. Sa'd and Z. Qadermazi, "Refusal strategies of Iranian University english as a foreign language and non-english learners in native language: A comparative study," Cent. Educ. Policy Stud. J., vol. 4, no. 4, pp. 121-142, 2014.

[14] E. Sarfo, "Variations in Ways of Refusing Requests in English among Members of a College Community in Ghana," African Nebul., no. 3, pp. 1-15, 2011.

[15] W. Y. Soe, "Translation Study Of Refusal Strategy In Beautiful Malice Novel (A Pragmatic Approach)," PRASASTI J. Linguist., vol. 3, no. 2, p. 235, Nov. 2018.

[16] N. Chojimah, "Refusal and Politeness Strategies in Relation to Social Status: A Case of Facethreatening Act among Indonesian University Students," Theory Pract. Lang. Stud., vol. 5, no. 5, p. 906, 2015.

[17] X. Li and J. Sun, "A Pragmatic Study in Refusal Strategies by Chinese College Nursing Majors," Cambridge J. China Stud., vol. 10, no. 2, p. 67, 2015.

[18] L. Kreishan, "Politeness and Speech acts of Refusal and Complaint among Jordanian Undergraduate Students," Int. J. Appl. Linguist. English Lit., vol. 7, no. 4, p. 68, 2018. 